\title{
Surgical treatment of giant cardiac aneurysm with pseudoaneurysm in a colon carcinoma patient
}

\author{
Tevfik Güneş ${ }^{1}$, Mohammad Alşalaldeh ${ }^{1}$, Ismail Doğu Kılıç², Bilgin Emrecan ${ }^{1}$ \\ ${ }^{1}$ Department of Cardiovascular Surgery, Faculty of Medicine, Pamukkale University, Denizli, Turkey \\ ${ }^{2}$ Department of Cardiology, Faculty of Medicine, Pamukkale University, Denizli, Turkey
}

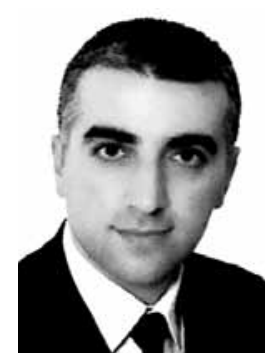

Kardiochirurgia i Torakochirurgia Polska 2015; 12 (2): 155-158

\begin{abstract}
Left ventricular pseudoaneurysm is a rare and lethal condition associated with a high risk of rapid enlargement and rupture. It develops after transmural myocardial infarction (MI), cardiac surgery, trauma, or infection. When a left ventricular pseudoaneurysm is detected, surgical repair is recommended due to the high possibility of rupture. In this report, we present surgical treatment of a giant cardiac pseudoaneurysm that occurred after $\mathrm{Ml}$ in a colon carcinoma patient.
\end{abstract}

Key words: aneurysm, cardiac, cancer, right ventricle, surgery.

\section{Introduction}

Left ventricular pseudoaneurysms are rarely seen cardiac diseases which occur after myocardial infarction (MI) or cardiac surgery $[1,2]$. They occur in $4 \%$ of patients after $\mathrm{MI}$ and in $23 \%$ of patients who die due to MI [3]. Adherence of pericardium causes pseudoaneurysm formation. In this case report we present surgical treatment of a giant cardiac pseudoaneurysm that occurred after $\mathrm{MI}$ in a colon carcinoma patient.

\section{Case study}

A 58-year-old man was admitted to the cardiology clinic with dyspnoea on exertion and rest (functional NYHA class IV). He was free from angina. He had orthopnea and paroxysmal nocturnal dyspnea. He had a history of colon adenocarcinoma and had been operated on for it (sigmoid colon resection and end-to-end anastomosis). He had been on chemotherapy after the surgery. He had an inferior MI history and 5 months before had presented with inferior Q waves on ECG. He had thoracic computed tomography (CT) 6 months before, demonstrating lung metastasis but normal mediastinal structures.

\section{Streszczenie}

Tętniak rzekomy lewej komory stanowi rzadkie i śmiertelnie niebezpieczne schorzenie związane z wysokim ryzykiem nagłego powiększenia się i pęknięcia zmiany. Do jego rozwoju dochodzi po pełnościennych zawałach serca, operacjach kardiochirurgicznych, urazach czy infekcjach. W wypadku wykrycia tętniaka rzekomego lewej komory zaleca się chirurgiczną korekcję zmiany ze względu na wysokie prawdopodobieństwo jej pęknięcia. W niniejszej pracy przedstawiono leczenie chirurgiczne gigantycznego tętniaka rzekomego serca, który rozwinął się po zawale mięśnia sercowego u pacjenta $z$ rakiem okrężnicy.

Słowa kluczowe: tętniak, sercowy, rak, prawa komora, chirurgia.

On physical examination, he had $4 / 6$ systolic murmur in the left $4^{\text {th }}$ intercostal space. He had fine rales on both sides in thoracic auscultation. A transthoracic echocardiogram (TTE) showed a dyskinetic inferior wall of the left ventricle, and severe mitral regurgitation due to chordal rupture. The left ventricular ejection fraction was 25\%. On the inferolateral wall there was a giant aneurysm formation, most of which was filled with thrombus. The pericardial and aneurysm wall was not distinguished. Coronary angiographic examination revealed patent anterior descending and circumflex arteries and totally occluded right coronary artery. In order to distinguish a true aneurysm from a pseudo-aneurysm, the patient was examined with thoracic CT angiography and cardiac magnetic resonance imaging (MRI). These imaging techniques were on the side of the pseudoaneurysm due to disappearance of the left ventricular wall on the inferior wall. There was also a true aneurysm on this side of the wall. There was a $100 \times 80 \mathrm{~mm}$ diameter aneurysmal enlargement, most of which was filled with thrombus (Fig. 1). The patient underwent a consultation with the oncologist. Having been given more than 1 year survival due to disappearance of most of the metastatic lung lesions, he decided to give a chance for surgical

Address for correspondence: Tevfik Güneş, MD, Pamukkale University, Faculty of Medicine, 20070 Denizli, Turkey, phone: 00905054644293 , e-mail: tevfik04@yahoo.com 


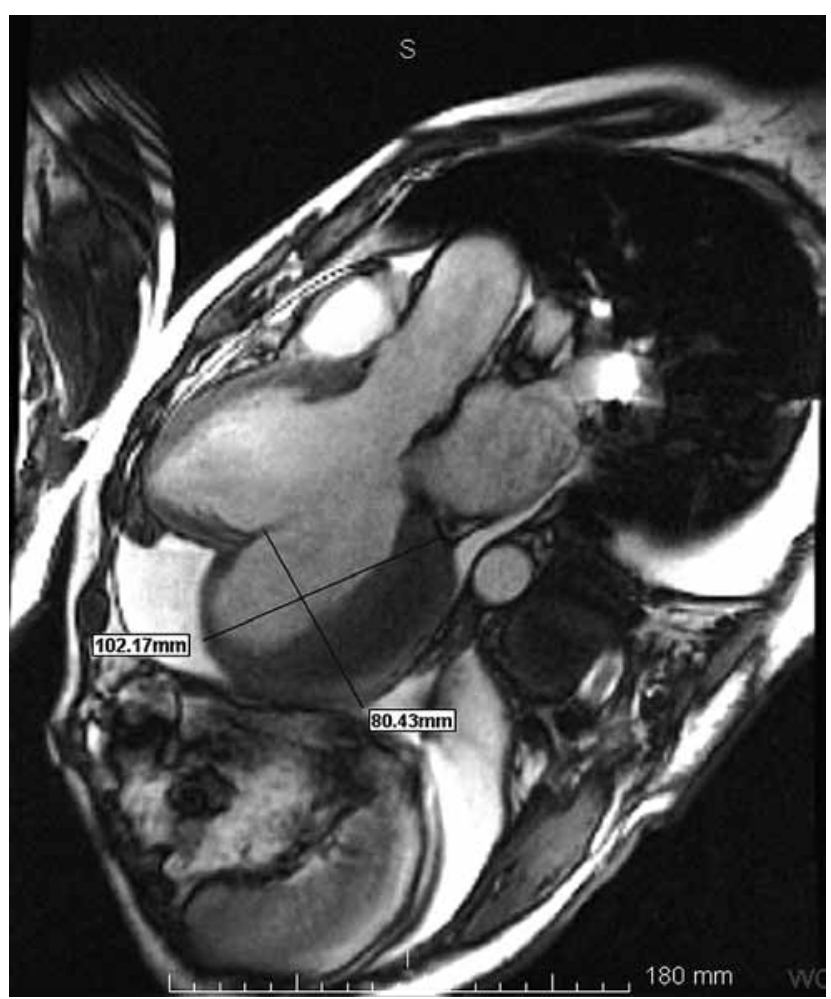

Fig. 1. Magnetic resonance imaging demonstrated a giant left ventricular pseudoaneurysm

correction. After giving his written consent he underwent the operation.

Under general anesthesia and intratracheal intubation, median sternotomy was done. There was giant aneurysmal formation on the inferolateral wall of the left ventricle, which strongly adhered to the pericardium (Fig. 2A). Standard cardiopulmonary bypass (CPB) techniques were used for the operations. After cardioplegic cardiac arrest had been achieved, the aneurysm was dissected from the adherent pericardium. There was a rupture on the aneurysmal sac (Fig. 2B). Thrombus was evacuated from the sac (Fig. 2C, D). Dor ventriculoplasty was done [4]. The defect was closed with an ePTFE patch (Fig. 3A). The left ventricle wall was closed with Teflon pledgets to reinforce the ventricle suture on the outside (Fig. 3B). The mitral valve was exposed through interatrial groove incision to the left atrium. The mitral valve was replaced with a mechanical prosthesis. The CPB was left with intra-aortic balloon pump counterpulsation and positive inotropic agent support. The patient was discharged on the $10^{\text {th }}$ day after the surgery without any complications. He is in his sixth postoperative month and is free of symptoms, and he is under chemotherapy for his colon carcinoma.

\section{Discussion}

This case is among the biggest aneurysms and pseudoaneurysms reported in the literature. The case is probably the biggest giant aneurysm located on the inferior wall that is ruptured, because posterior or inferior aneurysms represent $3 \%$ of all aneurysms. Posterior infarcts may involve papillary muscles and may be lethal due to severe mitral valve regurgitation [5].

For the diagnosis of the disease, we did not perform ventriculography for several reasons. First, the left ventricle was filled with large amounts of thrombus. Secondly, such a large pseudoaneurysm might be fatal in the case of even a small ventricular pressure increase or a touch with the catheter itself. MR, CT and TTE were done and preoperative diagnosis was confirmed in the operation. Large cardiac pseudoaneurysms are mostly seen after cardiac surgery, myocardial infarction, endocarditis, and chest trauma. Sometimes it may be a complication of Behçet's disease explained by myocardial fragility induced by ischemia due to the vasculitis process [6].

Cardiac pseudoaneurysms may cause a leak or rupture, or they can cause peripheral embolization [6]. Distinction of pseudoaneurysm from a true aneurysm can be difficult. A narrow neck on either color-flow Doppler echocardiography or ventriculography suggests pseudoaneurysm. The diameter of the neck is $50 \%$ smaller than the maximum diameter of the aneurysm itself [7].

The present case actually was a true aneurysm but the ventricular wall was not found at the pericardial adherence site. Therefore it may be called a pseudoaneurysm as well. The growth rate of the aneurysm was rapid. Coexisting malignancy with poor survival is mostly a contraindication for cardiac surgery. However, the present patient survived more than 1 year and we operated on him after consent was taken. Thanks to detailed evaluation and complete surgical correction, this patient is still in a good state and can take his oncologic medication.

In conclusion, malignancy should not contraindicate surgical repair, especially in patients with decompensated heart failure due to severe mitral regurgitation, even if they have severe comorbidities such as malignancy, because these patients probably would not survive without an intervention. Therefore we suggest a total correction of the mechanical complications of the $\mathrm{Ml}$ in order to achieve a better surgical outcome.

Consent: Written informed consent was obtained from the patient for publication of this case report and any accompanying images.

\section{Disclosure}

Authors report no conflict of interest. 

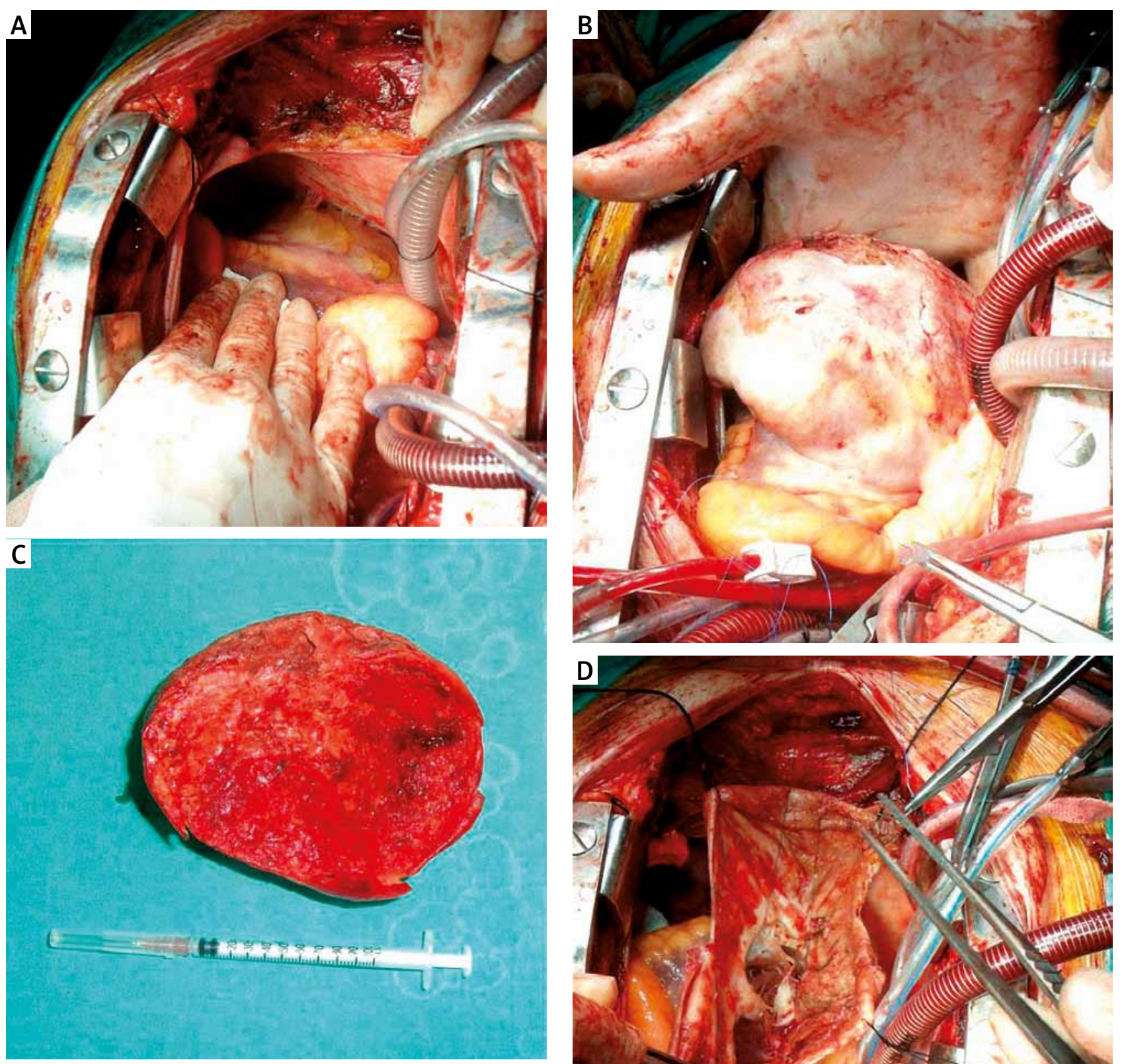

Fig. 2. A) Pseudoaneurysm with pericardial adhesions. B) Rupture of the aneurysmal sac. C) Huge thrombus extracted from sac. D) Pseudoaneurysm sac and the defect on the left ventricular wall

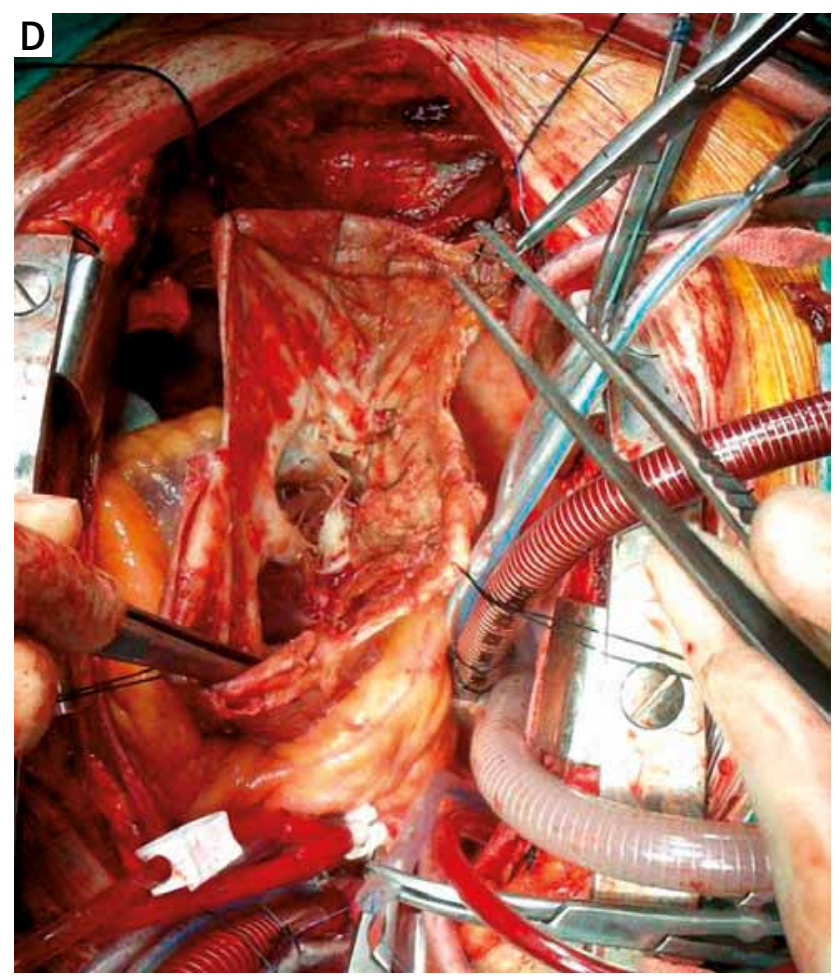



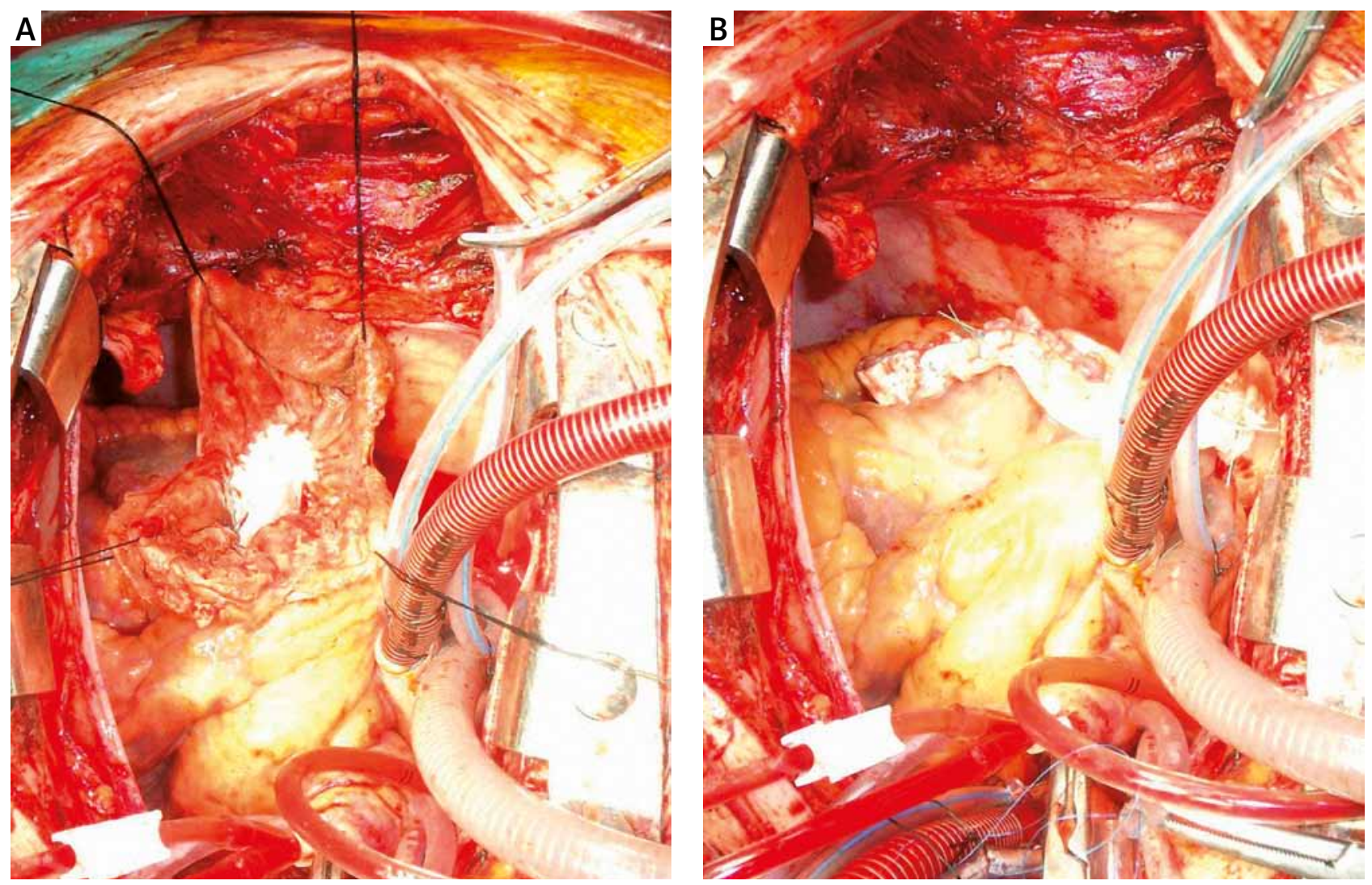

Fig. 3. Dor ventriculoplasty. A) The defect that is closed with an ePTFE patch. B) The left ventricle wall that is reinforced with Teflon pledgets

\section{References}

1. Koçak H, Becit N, Ceviz M, Unlü Y. Left ventricular pseudoaneurysm after myocardial infarction. Heart Vessels 2003; 18: 160-162.

2. Namboodiri N, Dora SK, Thomas B, Misra M. Subannular left ventricular pseudoaneurysm following mitral valve replacement. J Cardiothorac Surg 2008; 3: 28.

3. Pollak $\mathrm{H}$, Nobis $\mathrm{H}$, Mlczoch J. Frequency of left ventricular free wall rupture complicating acute myocardial infarction since the advent of thrombolysis. Am J Cardiol 1994; 74: 184-186.

4. Dor V, Saab M, Coste P, Kornaszewska M, Montiglio F. Left ventricular aneurysm: a new surgical approach. Thorac Cardiovasc Surg 1989; 37: 11-19.

5. Zoffoli G, Mangino D, Venturini A, Terrini A, Asta A, Zanchettin C, Polesel E. Diagnosing left ventricular aneurysm from pseudo-aneurysm: a case report and a review in literature. J Cardiothorac Surg 2009; 4: 11.

6. Marashi SM, Eghtesadi-Araghi P, Mandegar MH. A large left ventricular pseudoaneurysm in Behçet's disease: a case report. BMC Surg 2005; 5: 13.

7. Eren E, Bozbuga N, Toker ME, Keles C, Rabus MB, Yildirim O, Guler M, Balkanay $M$, Isik O, Yakut $C$. Surgical treatment of post-infarction left ventricular pseudoaneurysm: a two-decade experience. Tex Heart Inst J 2007; 34: 47-51. 